\title{
Modeling and Analysis of the Effects of Surface and Interface States on the Photocurrent and the Efficiency of a Solar Cell Based on n+npp+ Structure
}

\author{
E.M. Keita*, Y. Tabar, B. Ndiaye, A.A. Correa, C. Sene, B. Mbow \\ * Laboratoire des Semiconducteurs et d'Energie Solaire, Département de Physique, \\ Faculté des Sciences et Techniques, Université Cheikh Anta Diop, Dakar, Sénégal.
}

\begin{abstract}
In this article, we study the influence of interface and surface recombination effects on the performance of a solar cell and on the photocurrent profile. This study is applied to chalcopyrite thin film solar cell comprising 4 active layers following the model $\mathrm{ZnO}\left(\mathrm{n}^{+}\right) / \mathrm{CdS}(\mathrm{n}) / \mathrm{CuInS}_{2}(\mathrm{p}) / \mathrm{CuInSe}_{2}\left(\mathrm{p}^{+}\right)$where $\mathrm{CuInS}_{2}$ represents the base and $\mathrm{CuInSe}_{2}$ the substrate. It is based on the continuity equation of charge carriers in semiconductor material and the consideration of certain optical, geometric and electrical parameters (photon absorption coefficient, diffusion length, recombination velocity at the front and the back surface and at the interface between different layers, thicknesses of the layers, etc.). We also consider monochromatic illuminations ranging from visible to near infrared. The results obtained in two-dimensional and three-dimensional representations, show that surface and interface recombination centers can dramatically reduce the efficiency of the collection of carriers for certain wavelength ranges and that the efficiency depends on the area of photon absorption. The photons generated in the depletion area or close to this area are less affected by surface defects. The losses are related to the charge carriers which cross the interfaces to reach the depletion region and those which are generated in the vicinity of the surface because of the diffusion of the latter are towards the recombination centers.
\end{abstract}

KEYWORDS: Thin films, solar cell, surface and interface, charge carrier recombination

https://doi.org/10.29294/IJASE.8.3.2022.2328-2340

(C)2022 Mahendrapublications.com, All rights reserved

\section{INTRODUCTION}

Solar cells in thin layers are generally affected by recombinations of charge carriers at the surface and interface, this phenomenon reduces the collection of charge carriers and thus affecting the photocurrent delivered by the cell as well as the efficiency. The losses of carriers in surface are usually due to a break in the periodicity of the crystal lattice and the adsorption of foreign atoms causing multiple centers of recombination. In heterostructures, the state of interfaces has a key role in the transfer of charge carriers between layers. The interface of two different materials can present several recombination centers due to gaps in miscibility, lattice mismatch, differences electronic affinities, the formation of possible secondary phases, etc. [1]. Due to the presence of defects, the life time of the charge carriers at the surface and at the interface is generally less than their life time in bulk. The surface and interface states in this study are characterized by a surface recombination velocity and an interface recombination velocity respectively. A low recombination velocity models the presence of few recombination centers and therefore little losses of carriers and a high recombination velocity characterizes the presence of several recombination centers.

To model the influence of surface and interface states on solar cell efficiency, we consider 4-layer heterostructure defined by the model $\mathrm{ZnO}\left(\mathrm{n}^{+}\right) / \mathrm{CdS}(\mathrm{n}) / \mathrm{CuInS}_{2}(\mathrm{p}) / \mathrm{CuInSe}_{2}\left(\mathrm{p}^{+}\right)$. It is a decreasing band gap structure where the behavior of each layer can be seen on the spectral response, this type of structure allows avoiding the generation of hot carriers. $\mathrm{ZnO}$ and $\mathrm{CdS}$ are doped $\mathrm{n}$ [2-5], by aluminum (Al) for $\mathrm{ZnO}$ and indium (In) for CdS, their band gaps are respectively in order of $3 \mathrm{eV}$ and $2.35 \mathrm{eV}$ [6-7]. In the spectral range considered, ranging from near infrared to visible $(1.04 \mathrm{eV}-3.1 \mathrm{eV}), \mathrm{ZnO}$ and $\mathrm{CdS}$ are used as window layers allowing to move away the surface relatively to the active layers, $\mathrm{CdS}$ also plays the role of buffer layer allowing a good transition of lattice and electrical parameters between $\mathrm{ZnO}$, which has a low reflection coefficient [6] and the active layer $\mathrm{CuInS}_{2}$. The $\mathrm{CdS}$ with $\mathrm{CuInS}_{2}$ layers together form the space charge region (SCR). The $\mathrm{CuInS}_{2}$ and $\mathrm{CuInSe}_{2}$ of respective band gaps in order of $1.57 \mathrm{eV}$ and $1.04 \mathrm{eV}$ [6, 8-11], have rather similar electrical and structural parameters and 
are in the same family of chalcopyrite semiconductors [12-18]. These two materials act as absorbers. The $\mathrm{p}$ and $\mathrm{p}+$ doping allow to maintain the carriers in the base. In this work, the influence of the $\mathrm{CuInS}_{2} / \mathrm{CuInSe}_{2}$ interface on the internal quantum efficiency and on the photocurrent is largely highlighted

\section{DEFECTS AND PASSIVATION OF SURFACE AND INTERFACE OF CHALCOPYRITE MATERIALS BASED ON Cu(In,Ga)(Se,S)2 Defects in chalcopyrite solar cells}

With solar cells based on chalcopyrite materials, surface, interface and volume defects are generally due to several factors, some of which we will attempt to list are the one of the most illustrated in the literature. Generally, several techniques are used to develop solar cells based on $\mathrm{Cu}(\mathrm{In}, \mathrm{Ga})(\mathrm{S}$, $\mathrm{Se}$ ), among which we can mention co-evaporation process, selenization process, chemical vapor deposition, molecular beam epitaxy, electrodeposition, screen printing and particle deposition [19-20]. Thus, it generally results from the growth of the layers, the formation of defects which can vary from one method to another. These defects generally create recombination centers in volume, surface and interface; they can also modify the optical, electrical and structural properties of the layers. Generally the inter-diffusion and the mixing of the atoms after the deposition of the layers give rise to the formation of mixed compounds called secondary phases such as ternary phases $\mathrm{CuIn}_{3} \mathrm{Se}_{5}$ and $\mathrm{CuIn}_{5} \mathrm{Se}_{8}$, the binary phases $\mathrm{Cu}_{\mathrm{x}} \mathrm{Se}, \mathrm{Cu}_{2} \mathrm{Se}, \mathrm{In}_{2} \mathrm{Se}_{3}$, the vacancies of atoms such as $\mathrm{V}_{\mathrm{cu}}, \mathrm{V}_{\mathrm{In}}, \mathrm{V}_{\mathrm{Se}}$, the antisites such as $\mathrm{In}_{\mathrm{cu}}, \mathrm{Cu}_{\mathrm{In}}$, $\mathrm{Se}_{\mathrm{cu}}, \mathrm{Cu}_{\mathrm{Se}}, \mathrm{Se}_{\mathrm{In}}, \mathrm{In}_{\mathrm{Se}}$ and the interstitial sites such as $\mathrm{Cu}_{\mathrm{i}}, \quad \mathrm{In}_{\mathrm{i}}, \quad \mathrm{Se}_{\mathrm{i}}[20-21]$. These defects lead to recombination centers and introduce energy levels into the forbidden energy band. Generally the morphology of the elaborate layers often shows a high density and a three-dimensional distribution of defects, stacking faults and twins. The density of these defects varies according to the size of the crystal grains.

\section{Passivation methods}

To improve the performance of the solar cell, it is important to reduce the defects after the growth of the layers. Thus several methods are used to try to reduce the recombination centers. Surface passivation is a method widely used by manufacturers to reduce surface and interface recombination velocities to improve charge carrier collection and increase open-circuit voltage $\mathrm{V}_{\text {oc. }}$ We distinguish passivation methods such as passivation by thermal annealing which allows to lead to substantial grain sizes, the chemical passivation which makes it possible to reduce the number of electrically active defects by chemical treatment of the surface or the interface, passivation by field effect which is obtained by the presence of an integrated electric field which results from the high fixed charge density of the dielectric materials used of the passivation layer, this electric field keeps the charge carriers away from the recombination areas.

*Generally, smaller grain sizes are observed for films grown at lower substrate temperatures due to the lower mobility of atoms during growth. The annealing process at elevated temperatures leads to some improvement in the quality of the layers and the current-voltage (I-V) curves [20]. During thermal annealing, small grains may begin to develop up to a certain limit. If, on the other hand, larger grains are already formed during the deposition of the film at higher deposition temperatures, these grains will grow less, since they are already closer to final equilibrium, which is a satisfactory situation. Often films deposited at high temperature lead directly to a stable structure with less recrystallization and grain growth required. The crucial step in thermal annealing is the final film formation in a high temperature annealing process because the recrystallization process can compete with material decomposition. Thus post-annealing can improve ion diffusion and reduce defect density and dangling bonds, surface and interface recombination centers. After thermal annealing, the photoluminescence spectra generally show an improved lifetime of the minority charge carriers. Thus the internal quantum efficiency can be improved by thermal annealing after formation of the junction.

*The controlled and homogeneous incorporation of sodium $\mathrm{Na}$ into $\mathrm{Cu}(\mathrm{In}, \mathrm{Ga})(\mathrm{S}, \mathrm{Se})_{2}$ based solar cells also shows empirically better morphology and higher conductivity of the films. The incorporation of $\mathrm{Na}$ induces beneficial changes in the distribution of defects of absorbent films [2223]. This effect is mainly related to the passivation of grain boundary defects and an increase in charge carrier density.

*Aluminum oxide $\mathrm{Al}_{2} \mathrm{O}_{3}$ is also used as a passivation layer for surface and interface defects [24-25], it also reduces recombination centers in solar cells and increases their efficiency. Photoluminescence spectra obtained after adding a layer of aluminum oxide and a heat treatment often show a reduction of defects at the interfaces. A passivation layer based on $\mathrm{Al}_{2} \mathrm{O}_{3}$ can generally lead to three advantageous effects: chemical passivation; passivation by field effect; increased 
reflection of light at the back contact allowing more light to be absorbed by the active layer.

*Chemical treatments are also used at the surface of the absorbent film to passivate defects [26-27]. For example, immersion of the absorbent layer in a $10 \% \mathrm{KCN}$ solution to eliminate the $\mathrm{Cu}_{2-x} \mathrm{Se}$ secondary phase, the post-deposition sulfurtreatment (S-PDT) for $\mathrm{Cu}$-rich $\mathrm{CuInS}_{2}$ absorbent layers, trioctylphosphine Sulfide (TOP: S) solution treatment for $\mathrm{CuInSe}_{2}$ absorbent layers, the immersion of the CuInSe-based absorbent layer in solutions such as aqueous $\mathrm{Br}_{2}$ plus potassium bromide solution, etc. The aim of this work is not to grow layers $\mathrm{n}$ or does to characterize defects but it involves physically modeling the influence of surface and interface defects on the internal quantum efficiency, on the photocurrent and the direction of diffusion of the minority charge carriers in the solar cell under monochromatic illumination. This study is based on the charge carrier transport equation in semiconductor materials and the introduction of parameters that model the optical, electrical and structural properties of the material. The defect or purity states are reflected by the different values assigned to the modeling parameters. This study is done in two and three dimensions.

\section{THEORY AND METHOD}

The equations used to model the phenomena studied are based on the continuity equation of carriers in semiconductors, the generation rate is evidenced by the optical properties of the material, the purity of the material by the life time of the carriers in this case the diffusion coefficient and the diffusion length, and the states of surfaces and interfaces by the recombination velocities. It is assumed that the space charge region is located only between the $\mathrm{n}$ and $\mathrm{p}$ doped areas, the electric field is assumed to be zero outside this area. Optical reflections at the interface of each material are neglected.

In the case of the stationary regime, the continuity equation can be written:

$$
\begin{gathered}
\frac{1}{q} \operatorname{div} \overrightarrow{J_{n}}+g_{n}-r_{n}=0(I) \\
-\frac{1}{q} \operatorname{div} \overrightarrow{J_{p}}+g_{p}-r_{p}=0(I I)
\end{gathered}
$$

Without an electric field we have:

$$
\begin{aligned}
& \overrightarrow{J_{n}}=q D_{n} \cdot \overrightarrow{\operatorname{grad}}(n)(I I I) \\
& \overrightarrow{J_{p}}=-q D_{p} \cdot \overrightarrow{\operatorname{grad}}(p)(I V)
\end{aligned}
$$

We consider the one-dimensional case.

$\mathrm{n}$ and $\mathrm{p}$ represent the densities of electrons and holes in the material, respectively. $\mathrm{J}_{\mathrm{n}}$ and $\mathrm{J}_{\mathrm{p}}$ represent the current densities of electrons and holes, $g_{n}$ and $g_{p}$ the generation rates of carriers, $r_{n}$ and $r_{p}$ the recombination rates of carriers, $q$ is the elementary charge. In the case of solar cells, carriers are generated by light.

In Figures 1 we represent the optical absorption coefficients of the different materials and the $\mathrm{ZnO}$ reflection coefficient $[6-7,12]$. The diagram of the structure is shown in Figure 2.

\section{3-1. Photocurrent density in region 1-region 2}

In regions 1 and 2 ( $\mathrm{ZnO}$ and $\mathrm{CdS}$ ), the photocurrent is due to the photo-generated holes.The expression of the photocurrent density of holes in region 2 (CdS layer)noted $\mathrm{p}_{\mathrm{p}_{2}}(\mathrm{x})$, is given by previous studies [28-31], it is written as
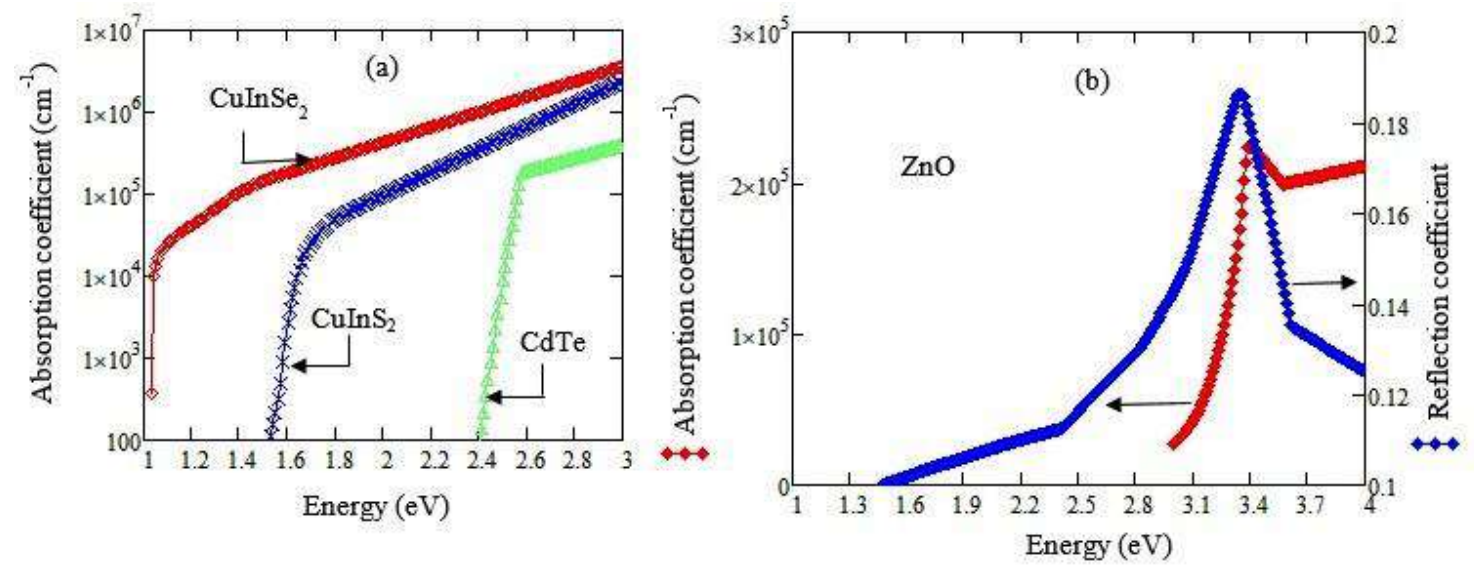

Figure 1. (a) Absorption coefficient of CdS, CuInS 2 , CuInSe 2 materials versus photon energy [7, 12] ; (b) Absorption coefficient and reflection coefficient of ZnO material versus photon energy [6] 


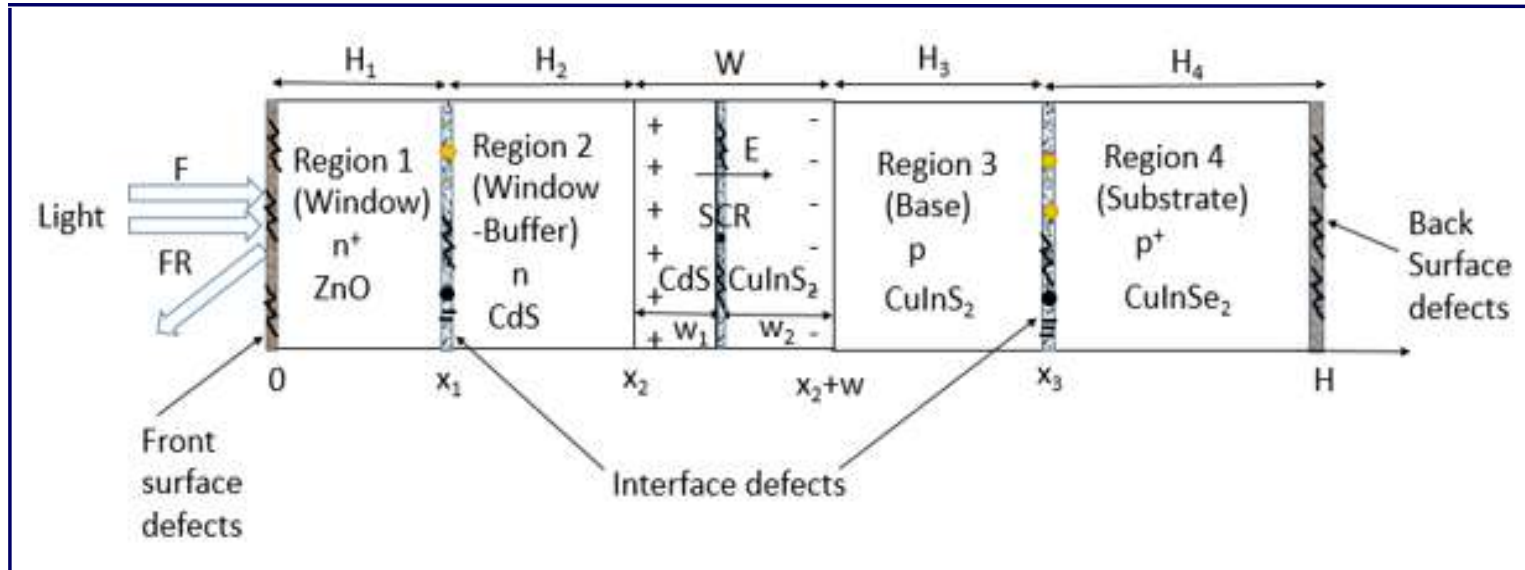

Figure 2. Diagram of the structure $\mathrm{ZnO}\left(\mathrm{n}^{+}\right) / \mathrm{CdS}(\mathrm{n}) / \mathrm{CuInS}_{2}(\mathrm{p}) / \mathrm{CuInSe}_{2}\left(\mathrm{p}^{+}\right)$

$$
\begin{aligned}
& J_{p_{2}}(x)=\frac{q \alpha_{2} F(1-R) L_{p_{2}} e^{-\alpha_{1} H_{1}}}{\left(\alpha_{2}{ }^{2} p_{p_{2}}{ }^{2}-1\right)}\left\{\frac{\left(\frac{S p_{2} L p_{2}}{D p_{2}}+\alpha_{2} L p_{2}\right) \operatorname{ch}\left(\frac{x-\left(H_{1}+H_{2}\right)}{L_{p_{2}}}\right)}{\frac{S p_{2} L p_{2}}{D p_{2}} \operatorname{sh}\left(\frac{H_{2}}{L p_{2}}\right)+c h\left(\frac{H_{2}}{L p_{2}}\right)}-\frac{e^{-\alpha_{2} H_{2}}\left[\frac{S p_{2} L p_{2}}{D p_{2}} \operatorname{ch}\left(\frac{x-H_{1}}{L p_{2}}\right)+\operatorname{sh}\left(\frac{x-H_{1}}{L p_{2}}\right)\right]}{\frac{S p_{2} L p_{2}}{D p_{2}} \operatorname{sh}\left(\frac{H_{2}}{L p_{2}}\right)+c h\left(\frac{H_{2}}{L p_{2}}\right)}-\alpha_{2} L_{p_{2}} e^{-\alpha_{2}\left(x-H_{1}\right)}\right\}+ \\
& \frac{\operatorname{ch}\left[\frac{x-\left(H_{1}+H_{2}\right)}{L p_{2}}\right] \times J_{p_{1}}\left(H_{1}\right)}{\left[\frac{S p_{2} L p_{2}}{D p_{2}} \operatorname{sh}\left(\frac{H_{2}}{L p_{2}}\right)+\operatorname{ch}\left(\frac{H_{2}}{L p_{2}}\right)\right]}(1)
\end{aligned}
$$

The photocurrent of holes in region 1 (ZnO layer) is represented by $\mathrm{J}_{\mathrm{p}_{1}}(\mathrm{x})$, it is also given by previous studies [28-31], $\mathrm{J}_{\mathrm{p}_{1}}\left(\mathrm{H}_{1}\right)$ is its expression for $\mathrm{x}=\mathrm{H}_{1}$. The expression of the photocurrent density of holes in region $1(\mathrm{ZnO})$ is written as :

$$
J_{p_{1}}(x)=\frac{q \alpha_{1} F(1-R) L_{p_{1}}}{\left(\alpha_{1}^{2} L_{p_{1}}{ }^{2}-1\right)} \times\left\{\frac{\left(\frac{S p_{1} L_{p_{1}}}{D p_{1}}+\alpha_{1} L_{p_{1}}\right) \operatorname{ch}\left(\frac{x-H_{1}}{L p_{1}}\right)-e^{-\alpha_{1} H_{1}}\left[\frac{S p_{1} L p_{1}}{D p_{1}} \operatorname{ch}\left(\frac{x}{L p_{1}}\right)+\operatorname{sh}\left(\frac{x}{L p_{1}}\right)\right]}{\frac{S p_{1} L p_{1}}{D p_{1}} \operatorname{sh}\left(\frac{H_{1}}{L p_{1}}\right)+c h\left(\frac{H_{1}}{L p_{1}}\right)}-\alpha_{1} L_{p_{1}} e^{-\alpha_{1} x}\right\}(2)
$$

The effects of the $\mathrm{ZnO} / \mathrm{CdS}$ interface are characterized by the recombination velocity $\mathrm{Sp}_{2}$ and those of the frontal surface of $\mathrm{ZnO}$ by $\mathrm{Sp}_{1} . \mathrm{Lp}_{1}$ and $\mathrm{Lp}_{2}$ represent the diffusion length of the holes respectively in regions 1 and 2 , these two parameters make it possible to model the state of the defects in the material in bulk, $\alpha_{1}$ and $\alpha_{2}$ represent the absorption coefficients of the two regions, they model the optical aspect of the materials.

\section{3-2. Photocurrent density in region 3 - region 4}

In regions 3 and $4\left(\mathrm{CuInS}_{2}\right.$ and $\left.\mathrm{CuInSe}_{2}\right)$ named respectively base and substrate, the continuity equations of the photo-generated electrons are written respectively:

$$
\begin{gathered}
\frac{d^{2} \Delta n_{3}}{d x^{2}}-\frac{\Delta n_{3}}{L_{n_{3}}^{2}}=\frac{-\alpha_{3}}{D_{n_{3}}} F(1-R) e^{-\alpha_{1} H_{1}} e^{-\alpha_{2}\left(H_{2}+w_{1}\right)} \times e^{-\alpha_{3}\left[x-\left(H_{1}+H_{2}+w_{1}\right)\right]}(3) \\
\frac{d^{2} \Delta n_{4}}{d x^{2}}-\frac{\Delta n_{4}}{L_{n_{4}}^{2}}=\frac{-\alpha_{4}}{D_{n_{4}}} F(1-R) e^{-\alpha_{1} H_{1}} e^{-\alpha_{2}\left(H_{2}+w_{1}\right)} \times e^{-\alpha_{3}\left(H_{3}+w_{2}\right)} e^{-\alpha_{4}\left[x-\left(H-H_{4}\right)\right]}(4)
\end{gathered}
$$

Boundary conditions can be written as [31-32] :

$$
\begin{gathered}
\Delta n_{3}=0 \text { for } x=x_{2}+w(5) \\
D_{n_{3}} \frac{d \Delta n_{3}}{d x}=-S_{n_{3}} \Delta n_{3}+D_{n_{4}} \frac{d \Delta n_{4}}{d x} \text { for } x=x_{3}(6)
\end{gathered}
$$




$$
\begin{gathered}
D_{n_{4}} \frac{d \Delta n_{4}}{d x}=-S_{n_{4}} \Delta n_{4} \text { for } x=H(7) \\
\Delta n_{4}=0 \text { for } x=x_{3}(8)
\end{gathered}
$$

The effects of the $\mathrm{CuInS}_{2} / \mathrm{CuInSe} \mathrm{I}_{2}$ interface are characterized by the recombination velocity $\mathrm{Sn}_{3}$ and those of the back surface of CuInSe $\mathrm{Sy} \mathrm{Sn}_{4}$. Ln represents the diffusion length of electrons and models the state of the defects in the material in bulk, Dn represents the diffusion coefficient, $\alpha$ represents the absorption coefficient and models the optical absorption of the material.

The expression of the photocurrent density of electrons in region 4 (CuInSe 2 layer or substrate) is given by :

$$
J_{n_{4}}(\mathrm{x})=q D_{n_{4}} \frac{d \Delta n_{4}}{d x}(9)
$$

It is written as :

$$
\begin{aligned}
& J_{n_{4}}(\mathrm{x})=-\frac{q \alpha_{4} L_{n_{4}} F(1-R) e^{\left[\left(\alpha_{2}-\alpha_{1}\right) H_{1}\right]} e^{\left[\left(\alpha_{3}-\alpha_{2}\right)\left(H_{1}+H_{2}+w_{1}\right)\right]}}{\left(\alpha_{4}{ }^{2} L_{n_{4}}{ }^{2}-1\right)} \times e^{\left[\left(\alpha_{4}-\alpha_{3}\right)\left(H-H_{4}\right)\right]} \times\left[\frac{\left(\alpha_{4} L_{n_{4}}-\frac{S_{n_{4} L_{n_{4}}}}{D_{n_{4}}}\right) e^{-\alpha_{4} H \cdot \operatorname{ch}\left(\frac{x-\left(H-H_{4}\right)}{L_{n_{4}}}\right)}}{\left.\frac{S_{n_{4} L_{n_{4}}} L\left(\frac{H_{4}}{D_{n_{4}}}\right)+\operatorname{ch}\left(\frac{H_{4}}{L_{n_{4}}}\right)}{L_{n_{4}}}\right)}+\right. \\
& \left.\frac{e^{-\alpha_{4}\left(H-H_{4}\right)}\left[\frac{S_{n_{4}} L_{n_{4}}}{D_{n_{4}}} \cdot \operatorname{ch}\left(\frac{H-x}{L_{n_{4}}}\right)+\operatorname{sh}\left(\frac{H-x}{L_{n}}\right)\right]}{\frac{S_{n_{4}} L_{n_{4}}}{D_{n_{4}}} \operatorname{sh}\left(\frac{H_{4}}{L_{n_{4}}}\right)+\operatorname{ch}\left(\frac{H_{4}}{L_{n_{4}}}\right)}-\alpha_{4} L_{n_{4}} e^{-\alpha_{4} x}\right](10)
\end{aligned}
$$

The expression of the photocurrent density of electrons in region 3 (CuInS 2 layer or base) is given by:

$$
J_{n_{3}}(\mathrm{x})=q D_{n_{3}} \frac{d \Delta n_{3}}{d x}(11)
$$

It is written as :

$$
J_{n_{3}}(\mathrm{x})=J_{n_{3 a}}(\mathrm{x})+J_{n_{3 b}}(\mathrm{x})(12)
$$

With :

$$
\begin{aligned}
& J_{n_{3 a}}(\mathrm{x})= \\
& -\frac{q \alpha_{3} L_{n_{3}} F(1-R) e^{\left[\left(\alpha_{2}-\alpha_{1}\right) H_{1}\right]} e^{\left[\left(\alpha_{3}-\alpha_{2}\right)\left(H_{1}+H_{2}+w_{1}\right)\right]}}{\left(\alpha_{3}{ }^{2} L_{n_{3}}{ }^{2}-1\right)} \times \\
& {\left[\frac{\left(\alpha_{3} L_{n_{3}}-\frac{S_{n_{3} L_{n_{3}}}}{D_{n_{3}}}\right) e^{-\alpha_{3}\left(H-H_{4}\right) \cdot \operatorname{ch}\left[\frac{x-\left(H_{1}+H_{2}+w\right)}{L_{n_{3}}}\right]}}{\frac{S_{n_{3} L_{n_{3}}}}{D_{n_{3}}} \operatorname{sh}\left[\frac{H_{3}}{L_{n_{3}}}\right]+\operatorname{ch}\left[\frac{H_{3}}{L_{n_{3}}}\right]}+\frac{e^{-\alpha_{3}\left(H_{1}+H_{2}+w\right)\left[\frac{S_{n_{3}} L_{n_{3}}}{D_{n_{3}}} \cdot \operatorname{ch}\left(\frac{\left(H-H_{4}\right)-x}{L_{n_{3}}}\right)+\operatorname{sh}\left(\frac{\left(H-H_{4}\right)-x}{L_{n_{3}}}\right)\right]}}{\frac{S_{n_{3} L_{n_{3}}}}{D_{n_{3}}} \operatorname{sh}\left[\frac{H_{3}}{L_{n_{3}}}\right]+\operatorname{ch}\left[\frac{H_{3}}{L_{n_{3}}}\right]}-\alpha_{3} L_{n_{3}} e^{-\alpha_{3} x}\right]} \\
& J_{n_{3 b}}(\mathrm{x})=-\frac{\operatorname{ch}\left[\frac{x-\left(H_{1}+H_{2}+w\right)}{L_{n_{3}}}\right] q \alpha_{4} L_{n_{4}} F(1-R) e^{\left[\left(\alpha_{2}-\alpha_{1}\right) H_{1}\right]}}{\left(\alpha_{4}{ }^{2} L_{n_{4}}{ }^{2}-1\right)\left\{\frac{S_{n_{3} L_{n_{3}}}}{D_{n_{3}}} \operatorname{sh}\left[\frac{H_{3}}{L_{n_{3}}}\right]+\operatorname{ch}\left[\frac{H_{3}}{L_{n_{3}}}\right]\right\}} \times e^{\left[\left(\alpha_{3}-\alpha_{2}\right)\left(H_{1}+H_{2}+w_{1}\right)\right]} e^{\left[\left(\alpha_{4}-\alpha_{3}\right)\left(H-H_{4}\right)\right]} \times\left[\frac{\left(\alpha_{4} L_{n_{4}}-\frac{S_{n_{4} L_{n_{4}}}}{D_{n_{4}}}\right) e^{-\alpha_{4} H}}{\frac{S_{n_{4} L_{n_{4}}}}{D_{n_{4}}} \operatorname{sh}\left(\frac{H_{4}}{L_{n_{4}}}\right)+c h\left(\frac{H_{4}}{L_{n_{4}}}\right)}+\right. \\
& \left.\frac{e^{-\alpha_{4}\left(H-H_{4}\right)}\left[\frac{S_{n_{4}} L_{n_{4}}}{D n_{4}} \cdot \operatorname{ch}\left(\frac{H_{4}}{L_{n_{4}}}\right)+\operatorname{sh}\left(\frac{H_{4}}{L_{n}}\right)\right]}{\frac{S_{n_{4} L} n_{4}}{D_{n_{4}}} \operatorname{sh}\left(\frac{H_{4}}{L_{n_{4}}}\right)+\operatorname{ch}\left(\frac{H_{4}}{L_{n_{4}}}\right)}-\alpha_{4} L_{n_{4}} e^{-\alpha_{4}\left(H-H_{4}\right)}\right]
\end{aligned}
$$

\section{3-3. Photocurrent density in the space charge region (SCR)}

In the space charge region, the recombinations of charge carriers are neglected. It is formed by two areas, $\mathrm{w}_{1}$ $(\mathrm{CdS})$ and $\mathrm{w}_{2}\left(\mathrm{CuInS}_{2}\right)$, the continuity equations for the photo-created holes can be written respectively:

$$
\begin{gathered}
-\frac{1}{q} \frac{d J_{w_{1}}}{d x}+\alpha_{2} F(1-R) e^{-\alpha_{1} H_{1}} e^{-\alpha_{2}\left(x-H_{1}\right)}=0(15) \\
-\frac{1}{q} \frac{d J_{w_{2}}}{d x}+\alpha_{3} F(1-R) e^{-\alpha_{1} H_{1}} e^{-\alpha_{2}\left(H_{2}+w_{1}\right)} \times e^{-\alpha_{3}\left[x-\left(H_{1}+H_{2}+w_{1}\right)\right]}=0(16)
\end{gathered}
$$


Boundary conditions can be written as:

$$
\begin{gathered}
J_{w_{1}}=0 \text { for } x=x_{2}(17) \\
J_{w_{2}}=0 \text { for } x=x_{2}+w_{1}(18)
\end{gathered}
$$

The photocurrent density of holes in the area $\mathrm{w}_{1}(\mathrm{CdS})$, is given by :

$$
J_{w_{1}}(x)=-q F(1-R) e^{-\alpha_{1} \cdot H_{1}} \times\left[e^{-\alpha_{2}\left(x-H_{1}\right)}-e^{-\alpha_{2} \cdot H_{2}}\right](19)
$$

The photocurrent density of holes in the area $\mathrm{w}_{2}\left(\mathrm{CuInS}_{2}\right)$ is given by :

$$
J_{w_{2}}(x)=-q F(1-R) e^{-\alpha_{1} H_{1}} e^{-\alpha_{2}\left(H_{2}+w_{1}\right)} \times\left[e^{-\alpha_{3}\left[x-\left(H_{1}+H_{2}+w_{1}\right)\right]}-1\right](20)
$$

\section{3-4. Total Photocurrent density}

Carriers which reach the space charge region are assumed to be collected. The total photocurrent collected is the sum of the photocurrents of the

$$
J_{p h}=J_{p_{2}}\left(\mathrm{x}_{2}\right)+J_{w_{1}}\left(x_{2}+w_{1}\right)+J_{w_{2}}\left(x_{2}+w\right)+J_{n_{3}}\left(x_{2}+w\right)(21)
$$

The internal quantum efficiency (or spectral response) IQE is given by [33] :

$$
\mathrm{IQE}=\frac{J_{p h}}{q F(1-R)}(22)
$$

\section{RESULTS AND DISCUSSION}

4-1. Spectral response graph

Figure 3 shows the internal quantum efficiency versus photon energy for different recombination velocities at the interface base-substrate $\mathrm{Sn}_{3}$, the diffusion length of electrons in the base is fixed at $\mathrm{Ln}_{3}=3 \mu \mathrm{m}$ and the base thickness is fixed at $\mathrm{H}_{3}=1$ $\mu \mathrm{m}$. This graph shows the influence of the recombination velocity on the collection efficiency. Figure 4 shows the internal quantum efficiency evolution versus the recombination velocity at the base-substrate interface $\mathrm{Sn}_{3}$ for different values of the radiation energy. The base thickness $\mathrm{H}_{3}$ is fixed at $1 \mu \mathrm{m}$ and the diffusion length $\operatorname{Ln}_{3}$ at $3 \mu \mathrm{m}$.

We note that the effect of the recombination velocity only affects the carriers (electrons) generated by photons having energy ranging between $1.04 \mathrm{eV}$ and $2 \mathrm{eV}$. Carriers generated in the substrate or near the base-substrate interface $(\mathrm{E}<1.57 \mathrm{eV})$ are more affected by the interface effects. However we note that for values of $\mathrm{Sn}_{3}$ lower than $2.10^{3} \mathrm{~cm} . \mathrm{s}^{-1}$, the internal quantum efficiency reaches its maximum value and becomes almost constant, this maximum value is between $65 \%$ and $97 \%$ for $1.04 \mathrm{eV}<\mathrm{E}<2 \mathrm{eV}$. The efficiency starts to decrease for values of $\mathrm{Sn}_{3}$ greater than $2.10^{3} \mathrm{~cm} . \mathrm{s}^{-1}$, then reaches its minimum value and becomes almost constant for values of $\mathrm{Sn}_{3}$ greater than $2.10^{6} \mathrm{~cm} . \mathrm{s}^{-1}$, this minimum value is between $0 \%$ and $85 \%$ for $1.04 \mathrm{eV}<\mathrm{E}<2 \mathrm{eV}$.

For radiation energy ranging between $2 \mathrm{eV}$ and $2.5 \mathrm{eV}$, all photons are practically absorbed by the space charge region (CdS $(0.02 \mu \mathrm{m}) / \mathrm{CuInS}_{2}(0.08$ $\mu \mathrm{m})$ ) and a thin thickness of the base $\left(\mathrm{CuInS}_{2}\right)$, theinternal quantum efficiency is close to $100 \%$. The recombination velocity at the interface become less influential on the collection efficiency

Beyond $2.5 \mathrm{eV}$ the photons are completely absorbed by the frontal layers according to the parameters that we have considered, the efficiency is independent of the recombination velocity at the base-substrate interface (case for $\mathrm{E}$ $=3.1 \mathrm{eV}$ ), it depends only on the parameters of the frontal layers ( $\mathrm{CdS}$ and $\mathrm{ZnO}$ ).

\section{4-2. Photocurrent densities of minoritycarriers evolution}

In this part, we study in the case of monochromatic illuminations, the profiles of the photocurrent densities versus junction depth. We consider radiation energies ranging between 1.04 $\mathrm{eV}(\lambda=1.192 \mu \mathrm{m})$ and $3.1 \mathrm{eV}(\lambda=0.4 \mu \mathrm{m})$. The following parameters are considered and are summarized in Table 1 :

Keita et al., 
$\mu \mathrm{m} ; H=100 \mu \mathrm{m} ; D p_{1}=0.51 \mathrm{~cm}^{2} . \mathrm{s}^{-1} ; D p_{1}=0.64$ $\mathrm{cm}^{2} \cdot \mathrm{s}^{-1} ; \mathrm{Dn}_{3}=5.13 \mathrm{~cm}^{2} \cdot \mathrm{s}^{-1} ; \mathrm{Dn}_{4}=10.27 \mathrm{~cm}^{2} \cdot \mathrm{s}^{-1}$

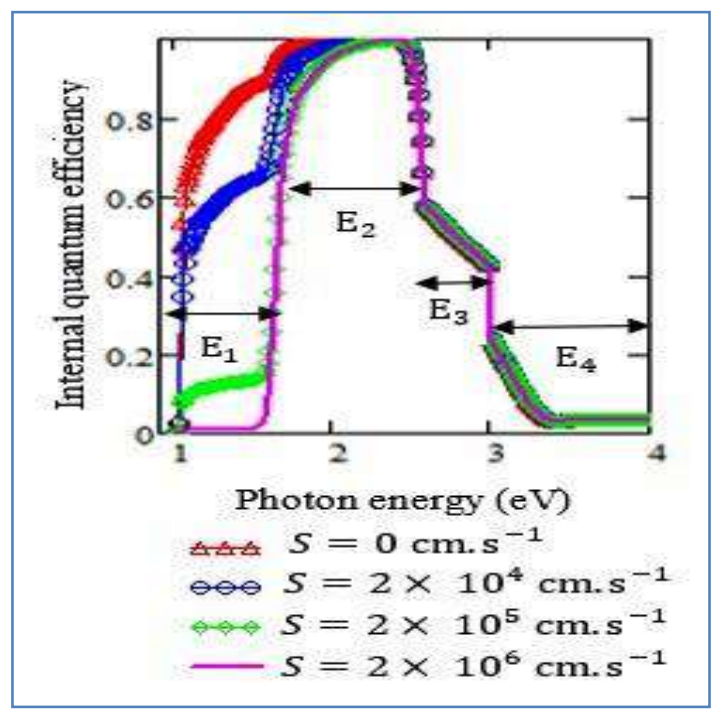

Figure 3. Internal quantum efficiency vs. photon energy for different values of the recombination velocity at the base-substrate interface $\mathrm{Sn}_{3}$ (region 3-region 4: $\mathrm{CuInS}_{2}$ - CuInSe 2 layers)

$\left(\mathrm{Sp}_{1}=2.10^{7} \mathrm{~cm} . \mathrm{s}^{-1} ; \mathrm{H}_{1}=0.3 \mu \mathrm{m} ; \mathrm{Lp}_{1}=0.3 \mu \mathrm{m} ; \mathrm{Sp}_{2}\right.$ $=2.10^{5} \mathrm{~cm} . \mathrm{s}^{-1} ; \mathrm{H}_{2}=0.1 \mu \mathrm{m} ; \mathrm{Lp}_{2}=0.4 \mu \mathrm{m} ; \mathrm{H}_{3}=1 \mu \mathrm{m}$ $; \mathrm{Ln}_{3}=3 \mu \mathrm{m} ; \mathrm{Sn}_{4}=2.10^{7} \mathrm{~cm} . \mathrm{s}^{-1} ; \mathrm{Ln}_{4}=1 \mu \mathrm{m} ; \mathrm{w}_{1}=$ $0.02 \mu \mathrm{m} ; \mathrm{w}_{2}=0.08 \mu \mathrm{m} ; \mathrm{W}=0.1 \mu \mathrm{m} ; \mathrm{H}=100 \mu \mathrm{m}$; $\mathrm{Dp}_{1}=0.51 \mathrm{~cm}^{2} . \mathrm{s}^{-1} ; \mathrm{Dp}_{1}=0.64 \mathrm{~cm}^{2} \cdot \mathrm{s}^{-1} ; \mathrm{Dn}_{3}=5.13$ $\mathrm{cm}^{2} . \mathrm{s}^{-1} ; \mathrm{Dn}_{4}=10.27 \mathrm{~cm}^{2} . \mathrm{s}^{-1}$ )

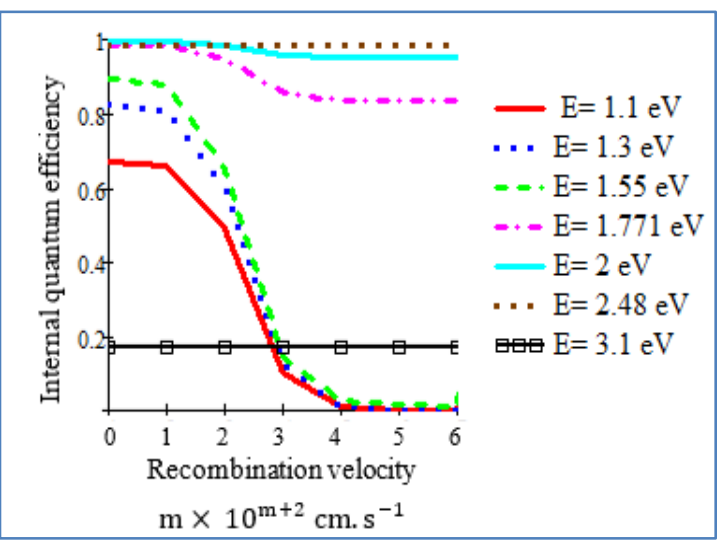

Figure 4.Internal quantum efficiency vs. recombination velocity at the base-substrate interface (region 3-region 4: $\mathrm{CuInS}_{2}-\mathrm{CuInSe}_{2}$ layers)

$\left(\mathrm{Sp}_{1}=2.10^{7} \mathrm{~cm} . \mathrm{s}^{-1} ; \mathrm{H}_{1}=0.3 \mu \mathrm{m} ; \mathrm{Lp}_{1}=0.3 \mu \mathrm{m} ; \mathrm{Sp}_{2}=\right.$ $2.10^{5} \mathrm{~cm} . \mathrm{s}^{-1} ; \mathrm{H}_{2}=0.1 \mu \mathrm{m} ; \mathrm{Lp}_{2}=0.4 \mu \mathrm{m} ; \mathrm{H}_{3}=1 \mu \mathrm{m}$ $; \mathrm{Ln}_{3}=3 \mu \mathrm{m} ; \mathrm{Sn}_{4}=2.10^{7} \mathrm{~cm} \cdot \mathrm{s}^{-1} ; \mathrm{Ln}_{4}=1 \mu \mathrm{m} ; \mathrm{w}_{1}=$ $0.02 \mu \mathrm{m} ; \mathrm{W}_{2}=0.08 \mu \mathrm{m} ; \mathrm{W}=0.1 \mu \mathrm{m} ; \mathrm{H}=100 \mu \mathrm{m}$; $\mathrm{Dp}_{1}=0.51 \mathrm{~cm}^{2} . \mathrm{s}^{-1} ; \mathrm{Dp}_{1}=0.64 \mathrm{~cm}^{2} . \mathrm{s}^{-1} ; \mathrm{Dn}_{3}=5.13$ $\mathrm{cm}^{2} . \mathrm{s}^{-1} ; \mathrm{Dn}_{4}=10.27 \mathrm{~cm}^{2} . \mathrm{s}^{-1}$ ) 4-2-1- Internal quantum efficiency

Figure 5 shows the contribution of each region on the internal quantum efficiency. Part $E_{1}$ (E
$<1.57 \mathrm{eV}$ ) shows the contribution of the substrate, it is less than $20 \%$, many carriers generated in the substrate are lost, these losses are caused by the interface effects $\left(\mathrm{Sn}_{3}=2.10^{5} \mathrm{~cm} \cdot \mathrm{s}^{-1}\right)$. Part $\mathrm{E}_{2}(1.57$ $\mathrm{eV}<\mathrm{E}<2.4 \mathrm{eV}$ ) shows the contributions of the base and the space charge region. The contribution of the base is also affected by carrier losses at the base-substrate interface, the maximum contribution of the base and substrate is less than $60 \%$. The contribution of the space charge region is important, it does not depend on the interface effects, its maximum contribution exceeds $90 \%$ for photon energy neighboring 2.3 $\mathrm{eV}$. Parts $E_{3}$ and $E_{4}$ show the absorption of photons by the frontal layers ( $\mathrm{CdS}$ and $\mathrm{ZnO}$ ) above $2.5 \mathrm{eV}$. Absorption of photons by these frontal layers reduces the overall efficiency, it is due to carrier losses by recombination phenomenon at the frontal surface $\left(\mathrm{Sp}_{1}=2.10^{7} \mathrm{~cm} \cdot \mathrm{s}^{-1}\right)$ and at the $\mathrm{ZnO} / \mathrm{CdS}$ interface $\left(\mathrm{Sp}_{2}=2 \cdot 10^{5} \mathrm{~cm} \cdot \mathrm{s}^{-1}\right)$.

Table 1 Physical parameters

\begin{tabular}{|c|c|c|c|c|}
\hline 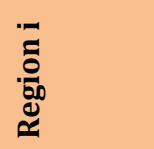 & $\underbrace{\Xi}_{=}$ & $\begin{array}{l}\Xi \\
\Xi \\
\Xi\end{array}$ & 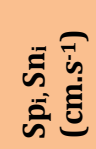 & 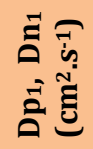 \\
\hline $\begin{array}{l}\mathrm{ZnO}\left(\mathrm{n}^{+}\right) \\
\text {(Region 1) }\end{array}$ & 0.3 & 0.3 & $2.10^{7}$ & 0.51 \\
\hline $\begin{array}{l}\text { CdS (n) } \\
\text { (Region 2) }\end{array}$ & 0.1 & 0.4 & $2.10^{5}$ & 0.64 \\
\hline $\begin{array}{l}\mathrm{CuInS}_{2}(\mathrm{p}) \\
\text { (Region 3: } \\
\text { Base) }\end{array}$ & 1.0 & 3.0 & $2.10^{5}$ & 5.13 \\
\hline $\begin{array}{l}\mathrm{CuInSe}_{2} \\
\left(\mathrm{p}^{+}\right) \\
\text {(Region 4: } \\
\text { Substrate) }\end{array}$ & 98.5 & 1.0 & $2.10^{7}$ & 10.27 \\
\hline
\end{tabular}

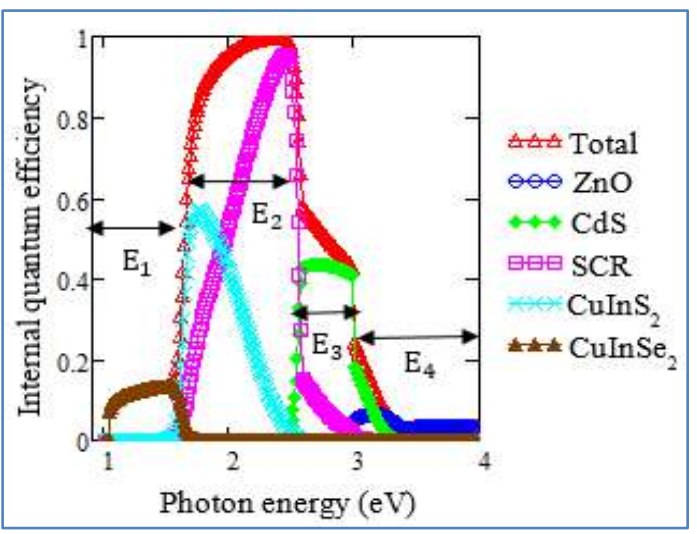

Figure 5.Internal quantum efficiency vs. photon energy

\section{Keita et al.,}




\section{4-2-2 Profiles of resulting photocurrent densities} of minority carriers

Figure 6 shows the photocurrent density of holes in $\mathrm{ZnO}$ layer (part $\mathrm{H}_{1}$ ) and $\mathrm{CdS}$ layer (part $\mathrm{H}_{2}$ ). For $\mathrm{E}$ $=3.1 \mathrm{eV}(\lambda=0.4 \mu \mathrm{m})$, the hole photocurrent observed in region 1 has a negative part (part $\mathrm{H}_{1-1}$ ) which models photocurrent losses in $\mathrm{ZnO}$ layer and a positive part (part $\mathrm{H}_{1-2}$ ) which models a diffusion of carriers towards the interface $\mathrm{ZnO}-\mathrm{CdS}\left(\mathrm{I}_{1-2}\right)$.

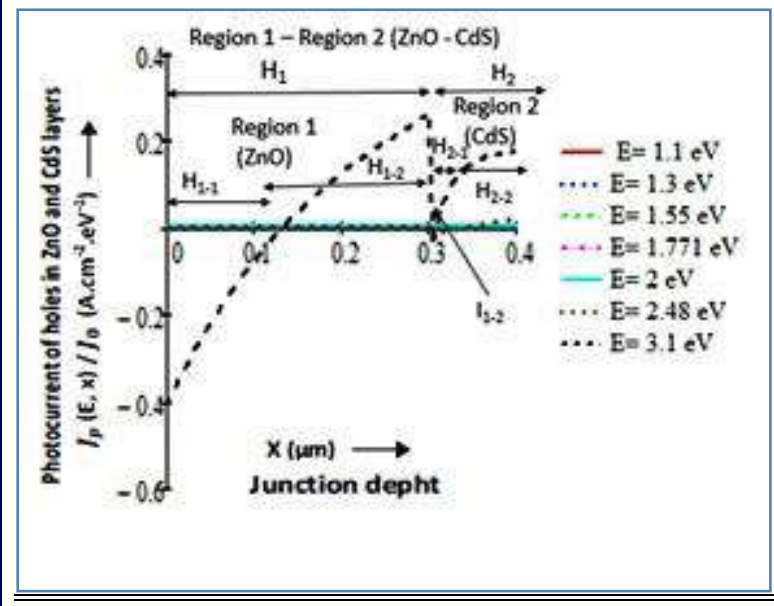

Figure 6 Photocurrent density of photocreated holes in regions 1 and 2 (ZnO-CdS) vs. junction depth (x) under monochromatic illuminations

Figure 7 represents the photocurrent density of electrons in the base $\left(\mathrm{CuInS}_{2}\right.$ : part $\left.\mathrm{H}_{3}\right)$ and the substrate $\left(\mathrm{CuInSe}_{2}\right.$ : part $\left.\mathrm{H}_{4}\right)$. In the substrate, a diffusion of electrons towards the interface is modeled by the positive part of the electron photocurrent (part $\mathrm{H}_{4-1}$ ); the negative part (part $\mathrm{H}_{4}$ 2) modeling photocurrent losses caused by the carriers that diffuse towards the back surface. In the base, the photocurrent of electrons due to photons having energy ranging between $1.04 \mathrm{eV}$ and $1.57 \mathrm{eV}$ (only absorbed by the substrate) is constant (curves $\mathrm{L}_{3}$ ). However, the photocurrent of electrons due to photons absorbed by the base $(\mathrm{E}=1.771 \mathrm{eV}$ and $\mathrm{E}=$ $2 \mathrm{eV}$ ) is not constant. This photocurrent increases near the collection area (space charge region) and is positive (part $\mathrm{H}_{3-1}$ ), the negative part of this photocurrent (part $\mathrm{H}_{3-2}$ ) models the diffusion of some electrons towards the base-substrate interface ( $\left.\mathrm{I}_{\mathrm{B}-\mathrm{Sub}}\right)$ where they will be lost by recombination phenomenon.

Figure 8 represents the photocurrent density of holes in the space charge region (parts $\mathrm{W}_{1}$ and $\mathrm{W}_{2}$ ). The absorption of photons by the space charge region $(\mathrm{E}=2.48 \mathrm{eV}, \mathrm{E}=2 \mathrm{eV}, \mathrm{E}=1.771 \mathrm{eV})$ considerably increases the photocurrent (part $\mathrm{W}_{2}$ ). In this region the elevated electrical field allows to neglect recombinations of carriers. This explains, on the spectral response curve, the great contribution of the space charge region for radiation energies ranging between $\mathrm{E}=1.771 \mathrm{eV}$ and $\mathrm{E}=2.48 \mathrm{eV}$ (Figure 5, part $\mathrm{E}_{2}$ ).

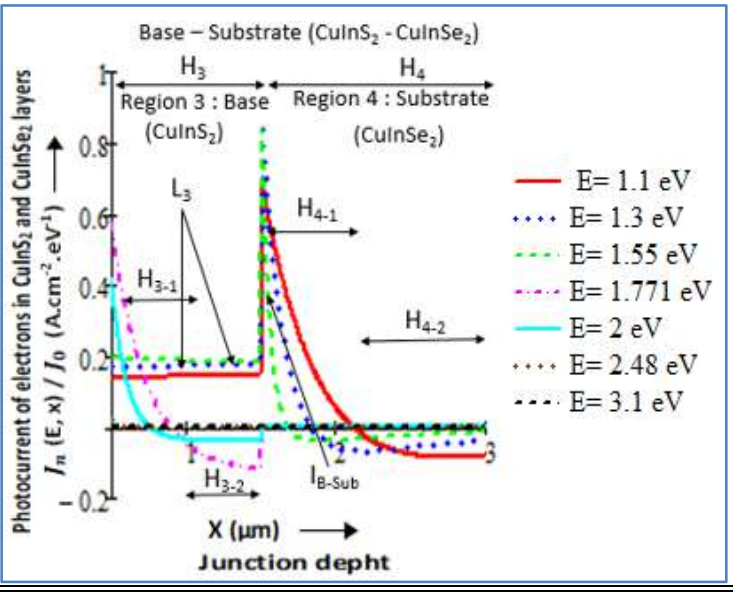

Figure 7 Photocurrent density of photo-created electrons in regions 3 and 4 (base and substrate: $\mathrm{CuInS}_{2}-\mathrm{CuInSe}_{2}$ ) vs. junction depth (x) under monochromatic illuminations

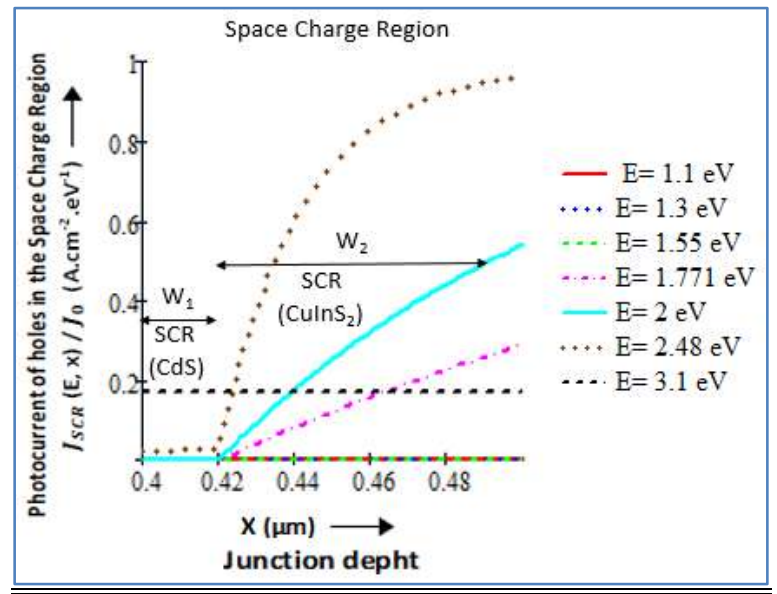

Figure 8 Photocurrent density of photo-created holes in the space charge region ( $\left.\mathrm{CdS} / \mathrm{CuInS} \mathrm{S}_{2}\right) \mathrm{vs}$. junction depth (x) under monochromatic illuminations

Figure 9 represent the resulting photocurrent density versus junction depth. For each considered energy, the total photocurrent is constant and results from the currents of holes and electrons. The photons mainly absorbed by the space charge region $(2 \mathrm{eV}<\mathrm{E}<2.48 \mathrm{eV}$ ) give the largest photocurrent (part J3), followed by those absorbed by the base $(1.57 \mathrm{eV}<\mathrm{E}<2 \mathrm{eV}$ ) (part J2), this explains the abrupt increase of the spectral response curve in the range $1.57 \mathrm{eV}<\mathrm{E}<2.48 \mathrm{eV}$ (Figure 5, part $\mathrm{E}_{2}$ ). Photons mainly absorbed by the substrate $(1.04 \mathrm{eV}$ $<\mathrm{E}<1.57 \mathrm{eV}$ ) give a low photocurrent (part J1) due to the losses of carriers at the base-substrate 
interface, explaining its weak contribution on the spectral response curve less than $20 \%$ (figure 5, part $E_{1}$ ).

The photons mainly absorbed by the front layers ( $\mathrm{ZnO}$ and $\mathrm{CdS}: \mathrm{E}>3 \mathrm{eV}$ ) also give a low photocurrent (part J1) due to losses of carriers by recombination phenomenon at the front surface of $\mathrm{ZnO}$ layer (region 1) and at the $\mathrm{ZnO} / \mathrm{CdS}$ interface (region 1 region 2), this explains the decrease of the spectral response curve for radiation energies greater than $2.5 \mathrm{eV}$ (Figure 5, parts $\mathrm{E}_{3}$ and $\mathrm{E}_{4}$ ).

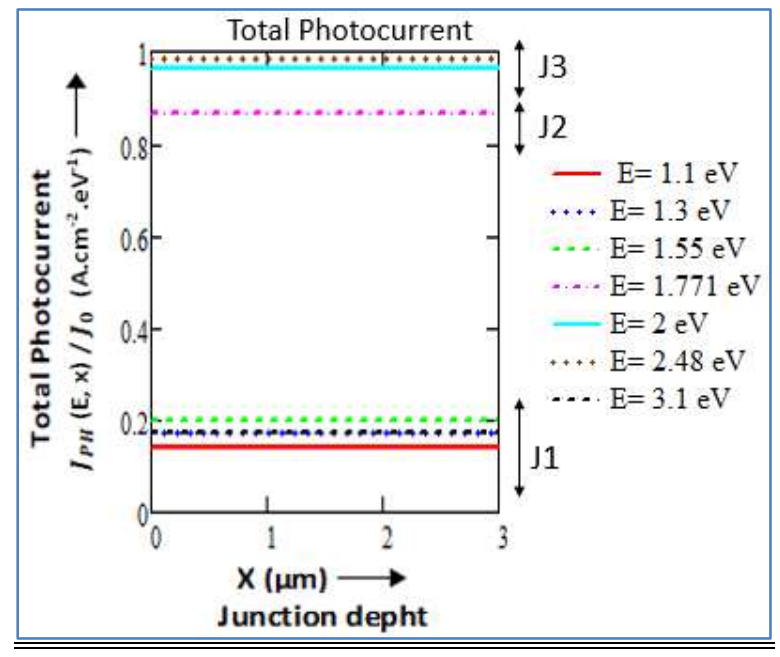

Figure 9 Total photocurrent density vs. junction depth (x) under monochromatic illuminations

\section{4-2-3 Three-dimensional representation photocurrent density profiles of minority carriers}

The photocurrent densities of minority carriers in $\mathrm{ZnO}$ and CdS layers, in the space charge region $\mathrm{CdS} / \mathrm{CuInS}{ }_{2}$ and in the $\mathrm{CuInS}_{2}$ and $\mathrm{CuInSe}_{2}$ layers are represented in three dimensions in Figures 10, 11 and 12 respectively. They are represented simultaneously versus photon energy and junction depth of the structure.

Figure 10 shows the evolution of the hole photocurrent in $\mathrm{ZnO}$ and $\mathrm{CdS}$ layers (parts $\mathrm{H}_{1}$ and $\mathrm{H}_{2}$ ). In the part $\mathrm{F} 1$ there is no photocurrent of holes in the front layers, the $\mathrm{ZnO}$ and $\mathrm{CdS}$ layers do not absorb incident photons $(\mathrm{E}<2.5 \mathrm{eV})$. The part $\mathrm{F} 2$ shows a positive photocurrent density of holes in $\mathrm{CdS}$ layer, the generated carriers diffuse towards the space charge region. In the part F3 there is almost no photocurrent density in the $\mathrm{CdS}$ layer (part $\mathrm{H}_{2}$ ), all the incident photons are absorbed by the $\mathrm{ZnO}$ layer (part $\mathrm{H}_{1}$ ). The part $\mathrm{J}_{\mathrm{S}}$ shows a negative hole photocurrent density in the ZnO layer, the carriers generated in this region are mainly lost by recombination, they diffuse towards the frontal surface.
Figure 11 shows the evolution of the photocurrent of holes in the space charge region $\left(\mathrm{CdS} / \mathrm{CuInS}_{2}\right)$. In the part S2 the photocurrent is essentially due to the $\mathrm{CuInS}_{2}$ layer. In the part S3 the photocurrent is due to the CdS and $\mathrm{CuInSe}_{2}$ layers, therefore the absorption of photons by the CdS layer reduces the photocurrent density in the space charge region. In the parts S1 and S4 there is no photocurrent, in the part $S 1$ the photons cross the space charge region without being absorbed, in the part S4 the photons do not reach the space charge region they are all absorbed by the frontal layers ( $\mathrm{ZnO}$ and $\mathrm{CdS}$ ). The photocurrent is maximal for photon energy neighboring the absorption gap of CdS layer (2.48 $\mathrm{eV}$ ) as shown by the spectral response curves.

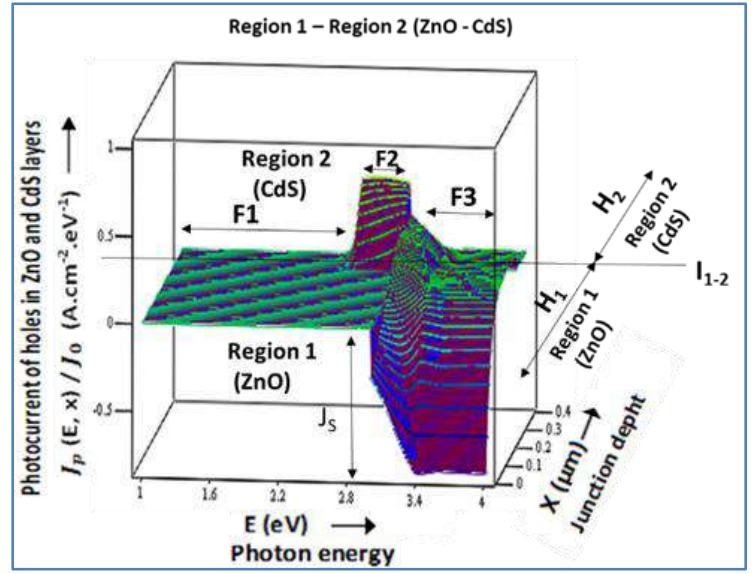

Figure 10 Three-dimensional representation photocurrent density of minority carriers vs. photon energy and junction depth (x): photocurrent density of holes in regions 1 and 2 (ZnO-CdS)

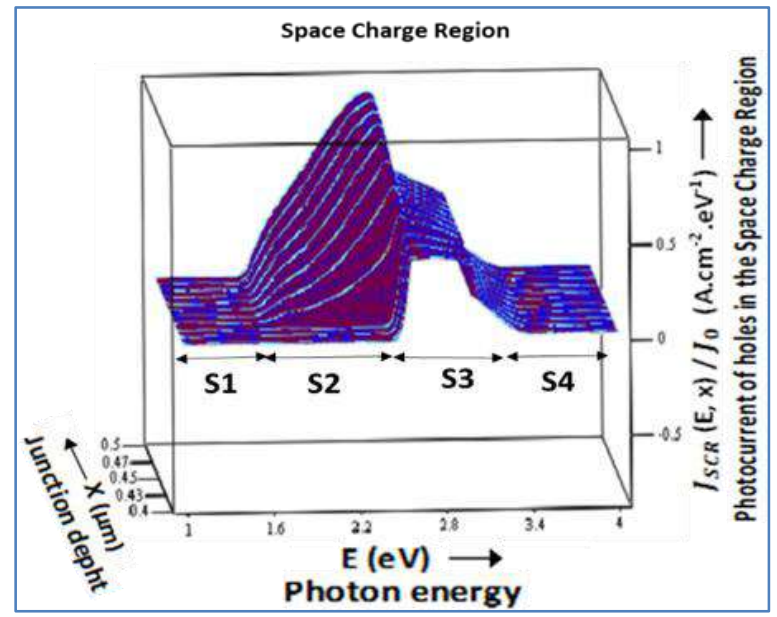

Figure 11 Three-dimensional representation Photocurrent density of minority carriers vs. photon energy and junction depth (x): photocurrent density of holes in the space charge region (CdS/ CuInS 2 ) 
Figure 12 shows the evolution of the electron photocurrent in the base and the substrate $\left(\mathrm{CuInS}_{2}\right.$ and $\mathrm{CuInSe}$ ). The part $\mathrm{H}_{4}$ shows the photocurrent of electrons in the substrate and the part $\mathrm{H}_{3}$ its evolution in the base. In the part BS2 photons do not reach the base and the substrate. The part B1 indicates the photocurrent of electrons due to the carriers generated in the substrate and the part B2 the photocurrent due to those generated mainly in the base. The behavior at the interface shows a discontinuity of the photocurrent ( $\mathrm{I}_{\mathrm{B}-\mathrm{Sub}}$ ).

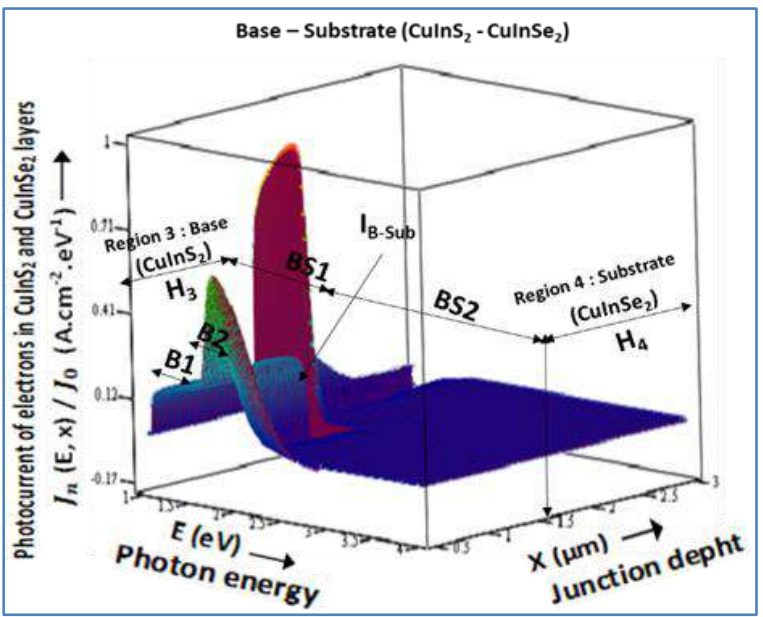

Figure 12 Three-dimensional representation Photocurrent density of minority carriers vs. photon energy and junction depth (x): photocurrent density of electrons in regions 3 and 4 (base and substrate : $\mathrm{CuInS}_{2}-\mathrm{CuInSe}_{2}$ )

\section{4-2-4 Profile of photocurrent densities of electrons and holes throughout the structure}

The total photocurrent density Jph is constant as shown in Figure 9. It is given by the sum of the current densities of electrons Jn (x) and holes Jp (x) at a given point. From this relation we can determine the expression of the electron and hole current densities over the whole structure using the following relation:

$$
\mathrm{Jn}(\mathrm{x})+\mathrm{Jp}(\mathrm{x})=\mathrm{Jph}
$$

Figures 13 and 14 respectively represent the profiles of photocurrent densities of holes and electrons for different radiation energies $(1.1 \mathrm{eV} \leq \mathrm{E}$ $\leq 3.1 \mathrm{eV}$ ) on the different regions of the solar cell structure $(0 \mu \mathrm{m} \leq \mathrm{x} \leq 3 \mu \mathrm{m})$. The profile of each photocurrent in $\mathrm{ZnO}$ and $\mathrm{CdS}$ layers is illustrated in part $\mathrm{H}_{1}-\mathrm{H}_{2}$. The part $\mathrm{W}_{-} \mathrm{H}_{3}$ shows the evolution of each photocurrent in the space charge region and the base, the part $\mathrm{H}_{4}$ shows its evolution in the substrate. The pics $\mathrm{I}_{1-2}$ and $\mathrm{I}_{\mathrm{B}-\mathrm{Sub}}$ of each photocurrent show respectively the $\mathrm{ZnO}-\mathrm{CdS}$ and $\mathrm{CuInS}_{2}$-CuInSe 2 interface effects.

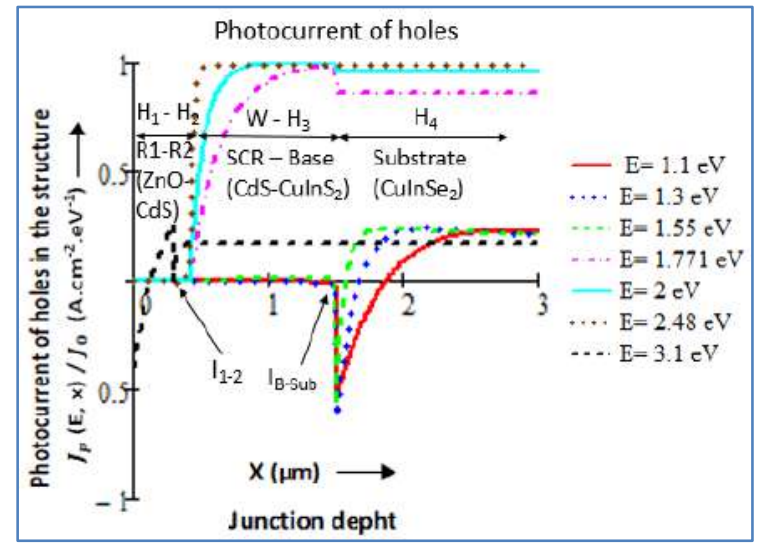

Figure 13 Photocurrent density of holes vs. junction depth (x) under monochromatic illuminations throughout the structure

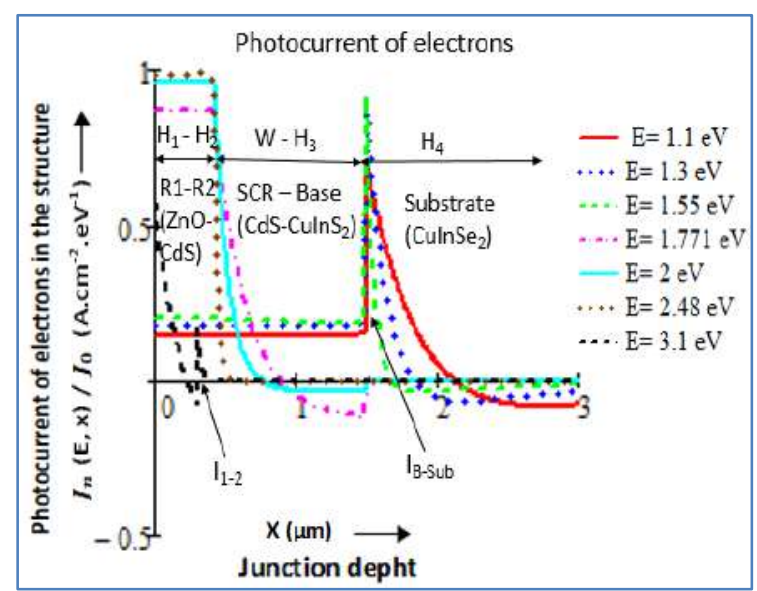

Figure 14 Photocurrent density of electrons vs. junction depth (x) under monochromatic illuminations throughout the structure

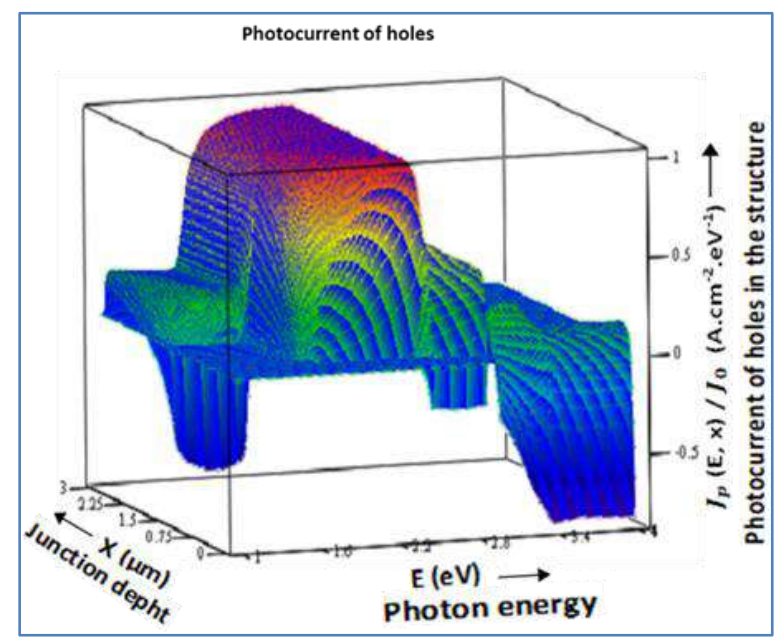

Figure 15 Three-dimensional representation photocurrent density of holes vs. photon energy and junction depth (x) throughout the structure 
Figures 15 and 16 represent respectively the three-dimensional representation of the graphs studied in Figures 13 and 14.

The three-dimensional representation is enough complex and depends on the view angle of graph (orientation of main axes), but it provides a detailed and simultaneous information of the profiles of photocurrent densities studied. However the twodimensional representation would allow a better interpretation of the different results.

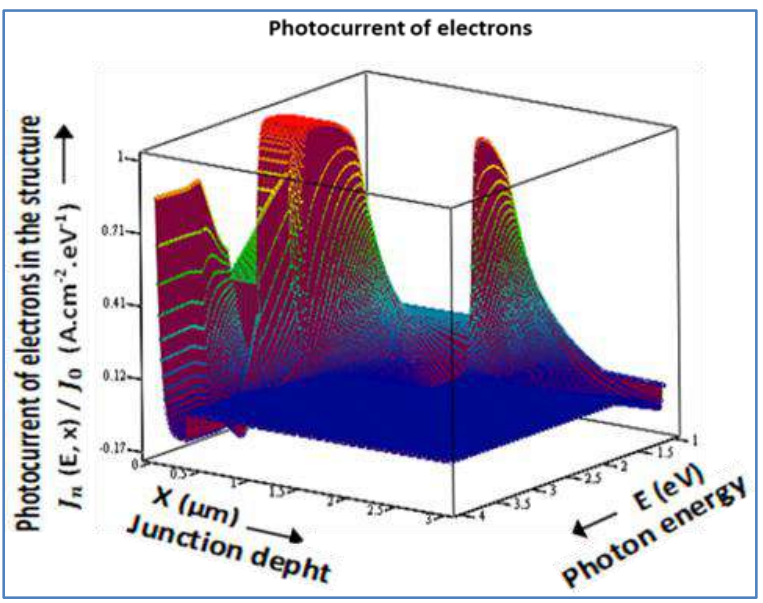

Figure 16 Three-dimensional representation photocurrent density of electrons vs. photon energy and junction depth (x) throughout the structure

\section{CONCLUSION}

In this work, the 4-layer structure $\mathrm{ZnO}\left(\mathrm{n}^{+}\right) / \mathrm{CdS}(\mathrm{n}) / \mathrm{CuInS}_{2}(\mathrm{p}) / \mathrm{CuInSe}_{2}\left(\mathrm{p}^{+}\right)$(model $\mathrm{n}^{+}$/ $\mathrm{n} / \mathrm{p} / \mathrm{p}^{+}$) is considered. We have studied the response of the structure under monochromatic illuminations in order to visual interface and surface effects on the performances of the solar cell. For this study, on the one hand, the spectral response has been represented by varying recombination velocity at the interface. As we have used window layers in the frontal area ( $\mathrm{ZnO}$ and $\mathrm{CdS}$ ), the variation of the parameters concerns only the rear area (base and substrate: $\mathrm{CuInS}_{2}, \mathrm{CuInSe} 2$ ). The results obtained show that the spectral response depends on the recombination velocities and their optimization is essential for a best collection of carriers and a better performance of the structure. The influence of the interface and the surface depend on the energy (wavelength) of photons. The photons generated in the depletion area (space charge region) or close to this region are less affected by the surface states. The absorption of the frontal layers causes a drop of the internal quantum efficiency; this drop is due to the recombination of carriers at the surface, interface and in bulk in these layers. An optimal recombination velocity is less than $2.10^{3} \mathrm{~cm} . \mathrm{s}^{-1}$, in this range the efficiency becomes maximum and independent of the recombination rate. On the other hand, for a recombination velocity greater than $2.10^{6} \mathrm{~cm} . \mathrm{s}^{-1}$, the efficiency reaches its minimum value.

On the other hand, to study the intrinsic behavior of the structure, we have represented the photocurrent density profiles of holes and electrons for different illuminations, in two and three dimensions, taking into account junction depth and photon energy. The collection of carriers generated near the interface or beyond this area depends strongly on the state of the latter. Many carriers generated in the substrate are lost crossing the base-substrate interface. To be collected, the carriers must diffuse towards the depletion region where they can be accelerated by the electric field to generate current, the recombinations at the surface and interface create a concentration gradient of the charge carriers causing the diffusion of the latter towards the recombination centers where they will be lost, many charge carriers generated in the base are affected by this phenomenon. The charge carriers generated in bulk far from the interfaces naturally diffuse towards the rear surface and will be lost by recombination phenomenon.

This study allows visualizing the behavior of the photocurrent density of carriers in the different areas of the structure, to identify the influence of the parameters and to locate the carrier losses by recombination in surface and interface, depending on photon energy. Thus, it allows showing the importance of the surface and interface states on the efficiency of the solar cell.

\section{Nomenclature}

F: Incident photons flux $\left(\mathrm{cm}^{-2} \cdot \mathrm{s}^{-1}\right)$

R: Reflection coefficient of region $1(\mathrm{ZnO})$

Jph: Total density of photocurrent $\left(A \cdot \mathrm{cm}^{-2} \cdot \mathrm{eV}^{-1}\right)$

$\mathrm{H}$ : Thickness of the structure $(\mu \mathrm{m})$

$\mathrm{w}_{1}$ : Thickness of CdS layer in the space charge region (SCR) $(\mu \mathrm{m})$

$\mathrm{w}_{2}$ : Thickness of $\mathrm{CuInS}_{2}$ layer in the space charge region (SCR) $(\mu \mathrm{m})$

$\mathrm{w}$ : Thickness of the space charge region $(\mu \mathrm{m})$

$\mathrm{J}_{\mathrm{w} 1}$ : Photocurrent density of holes in CdS layer in the space charge region (SCR) (A.cm- $\left.{ }^{-2} \cdot \mathrm{eV}^{-1}\right)$

$\mathrm{J}_{\mathrm{w} 2}$ : Photocurrent density of holes in $\mathrm{CuInS}_{2}$ layer in the space charge region (SCR) $\left(\mathrm{A} \cdot \mathrm{cm}^{-2} \cdot \mathrm{eV}^{-1}\right)$

$\mathrm{q}$ : Elementary charge $\left(1.6 \times 10^{-19} \mathrm{C}\right)$ 


\section{Table 2.Nomenclature}

\begin{tabular}{|c|c|c|c|c|}
\hline Parameter & $\begin{array}{c}\operatorname{ZnO}\left(\mathrm{n}^{+}\right) \\
\text {(Region 1) }\end{array}$ & $\begin{array}{c}\text { CdS (n) } \\
\text { (Region 2) }\end{array}$ & $\begin{array}{l}\text { CuInS } 2 \text { (p) } \\
\text { (Region 3: } \\
\text { Base) }\end{array}$ & $\begin{array}{c}\mathrm{CuInSe}_{2}\left(\mathrm{p}^{+}\right) \\
\text {(Region 4: } \\
\text { Substrate) }\end{array}$ \\
\hline Minority carriers & $\begin{array}{l}\text { Holes } \\
\text { (p) }\end{array}$ & $\begin{array}{l}\text { Holes } \\
\text { (p) }\end{array}$ & $\begin{array}{l}\text { Electrons } \\
\text { (n) }\end{array}$ & Electrons (n) \\
\hline $\begin{array}{l}\text { Absorption coefficient } \\
\left(\mathrm{cm}^{-1}\right)\end{array}$ & $\alpha_{1}$ & $\alpha_{2}$ & $\alpha_{3}$ & $\alpha_{4}$ \\
\hline $\begin{array}{l}\text { Diffusion coefficient } \\
\mathrm{cm}^{2} \cdot \mathrm{s}^{-1}\end{array}$ & $D_{p_{1}}$ & $D_{p_{2}}$ & $D_{n_{3}}$ & $D_{n_{4}}$ \\
\hline Diffusion length $(\mu m)$ & $L_{p_{1}}$ & $L_{p_{2}}$ & $L_{n_{3}}$ & $L_{n_{4}}$ \\
\hline $\begin{array}{l}\text { Recombination velocity } \\
\text { (surface or interface) } \\
\left(\mathrm{cm} . \mathrm{s}^{-1}\right)\end{array}$ & $S_{p_{1}}$ & $S_{p_{2}}$ & $S_{n_{3}}$ & $S_{n_{4}}$ \\
\hline Thickness $(\mu m)$ & $H_{1}$ & $H_{2}$ & $H_{3}$ & $H_{3}$ \\
\hline $\begin{array}{l}\text { Density (electrons or } \\
\text { holes) }\left(\mathrm{cm}^{-3}\right)\end{array}$ & $\Delta p_{1}$ & $\Delta p_{2}$ & $\Delta n_{3}$ & $\Delta n_{4}$ \\
\hline $\begin{array}{l}\text { Photocurrent density } \\
\text { (electrons or } \\
\text { holes }\left(A . \mathrm{cm}^{-2}\right) \text { ) }\end{array}$ & $J_{p_{1}}$ & $J_{p_{2}}$ & $J_{n_{3}}$ & $J_{n_{4}}$ \\
\hline
\end{tabular}

\section{REFERENCES}

[1] Kulwinder Kaur, Naveen Kumar and Mukesh Kumar, Strategic review of interface carrier recombination in earth abundant $\mathrm{Cu}-\mathrm{Zn}-\mathrm{Sn}-\mathrm{S}-\mathrm{Se}$ solar cells: current challenges and future prospects', J. Mater. Chem. A, 2017, 5, 3069-3090.

[2] Wolf, H.F. 1971.Semiconductors, Wiley Interscience, New York, NY.

[3] SavelliandJ. Bougnot, M. 1979.Problems of the CuZS/CdS Cell, in Solar Energy, Solid State Physics Aspects (B. O. Seraphin, ed.). 31. Topics in Applied Physics, p. 213. Springer-Verlag, Berlin and New York.

[4] Feucht, D.L.1977. Heterojunctions in photovoltaic devices, J. Vac. Sci. Technol. 14, 57.

[5] Lupan, O., Pauporte, T., Chow, L., Viana, B., Pelle, F., Ono, L.K. 2010. Effects of annealing on properties of $\mathrm{ZnO}$ thin films prepared by electrochemical deposition in chloride medium, Appl. Surf. Sci. 256, 1895.

[6] Hisashi Yoshikawa, Sadao Adachi.1997. Optical Constants of $\mathrm{ZnO}$, Jpn. J.Appl. Phys. 36, 6237-6243.

[7] Subba Ramaiah Kodigala. 2010. Cu( $\operatorname{In}_{1}$ xGax)Sez based thin solar cells, 35, Academic Press, ELSEVIER.Inc.

[8] Yakushev, M.V., Mudryi, A.V., Gremenok, V.F. , Zalesski, V.B., Romanov, P.I., Feofanov, Y.V., Martin, R.W., Tomlinson, R.D. 2003.0ptical properties and band gap energy of $\mathrm{CuInSe}_{2}$ thin films prepared by two-stage selenization process, Journal of Physics and Chemistry of Solids, 64, 20052009.

[9] Ariswan, G. El Haj Moussa, F. Guastavino, C. Llinares, Band gap of CuInSe2 thin films fabricated by flash evaporation determined from transmission data, Journal of Materials Science Letters, 21, 215-217.

[10] S. B. Zhang, Su-Huai Wei, and Alex Zunger. 1997. Stabilization of Ternary Compounds via Ordered Arrays of Defect Pairs, Phys. Rev. Lett, 78, 4059

[11] AbazovićNadica D., JovanovićDragana J., Stoiljković Milovan M., MitrićMiodrag N., Ahrenkil Phillip S., Nedeljković Jovan M., ČomorMirjana I.2012. 'Colloidal-chemistry based synthesis of quantized $\mathrm{CuInS}_{2} / \mathrm{Se}_{2}$ nanoparticles', Journal of the Serbian Chemical Society, 77, 789-797.

[12] Keita, E.M., Mbow, B., Mane, M.S.,Sow, M.L., Sene. C. 2016. Theoretical Study of Spectral Responses of Homojonctions Based on CuInSe2, Journal of Materials Science \& Surface Engineering, 4 (4)392-399.

[13] Robbins, M., Lambrecht Jr. V.G. 1973. Preparation and some properties of materials in systems of the type MIMIIIS 2 / MIMIIISe $_{2}$ where $\mathrm{MI}=\mathrm{Cu}, \mathrm{Ag}$ and $\mathrm{MIII}=\mathrm{Al}$, Ga, In, Mater. Res. Bull. 8,703. 
[14] Fonash, S.J. 1981.Solar Cell device Physics, Academic Press, New York.

[15] Loher, T., Jaegermann, W. , Pettenkofer. C. 1995. Formation and electronic properties of the $\mathrm{CdS} / \mathrm{CuInSe}_{2}$ (011) heterointerface studied by synchrotron-induced photoemission, J. Appl. Phys. 77,731.

[16] Hwang, H.L, Sun, C.Y., Leu, C.Y., Cheng, C.C,. Tu. C.C. 1978. Growth of $\mathrm{CuInS}_{2}$ and its characterization, Rev. Phys. Appl. 13,745.

[17] Hahn, H., Frank, G., Klinger, W., Meyer, A.D. Strorger. G. 1953. Über einigeternäre Chalkogenidemit Chalcopyrite struktur" Z. Anorg. Aug. Chem. 271,153.

[18] Bodnar, I.V., Korzun, B.V., Lukomski. A.I. 1981. 'Composition Dependence of the Band Gap of CuInS ${ }_{2 x} S_{2(1-x)}$, Phys. Stat. Solidi (B) 105. K143.

[19] Lincot, D., Guillemoles, J.-F., Cowache, P., Marlot, A., Lepiller, C., Canava, B., Yousfi, F.B. and Vedel, J.1998. Solution deposition technologies for thin film solar cells: status and perspectives, Proc. 2ndWorld Conf. on Photovoltaic Solar Energy Conversion, Vienna, 440.

[20] Tom Markvart and Castañer. 2003.Practical Handbook of Photovoltaics, Fundamentals and Applications,1st edition - october 30, 2003, p. 334-401

[21] Abou-Elfotouh, F.A., Moutinho, H., Bakry, A., Coutts, T.J. and Kazmerski, L.L.1991. Characterization of the defect levels in copper indium diselenide". Solar Cells, 30, 151.

[22] Keyes, B.M., Hasoon, F., Dippo, P., Balcioglu, A. and Abouelfotouh, F.1997. Influence of $\mathrm{Na}$ on the elctro-optical properties of $\mathrm{Cu}(\mathrm{In}, \mathrm{Ga}) \mathrm{Se}_{2}$, Proc. 26th. TEEE Photovoltaic Specialists Conf., Anaheim, 479.

[23] Rau, U., Schmitt, M., Engelhardt, F., Seifert, O., Parisi, J., Riedl, W., Rimmasch, J. and Karg, F. 1998. Impact of $\mathrm{Na}$ and $\mathrm{S}$ incorporation on the electronic transport mechanisms of $\mathrm{Cu}(\mathrm{In}, \mathrm{Ga}) \mathrm{Se}_{2}$ solar cells, Solid StateCornrnun., 107, 59.

[24] Hsu,W.-W.; Chen, J.Y.; Cheng, T.-H.; Lu, S.C.; Ho, W.-S.; Chen, Y.-Y.; Chien, Y.-J.; Liu, C.W.2012. Surface passivation of $\mathrm{Cu}(\mathrm{In}, \mathrm{Ga}) \mathrm{Se}_{2}$ using atomic layer deposited $\mathrm{Al}_{2} \mathrm{O}_{3}$, Appl. Phys. Lett. 100, 023508.
[25] Chan Hyeon Park, Jun Yong Kim, Shi-Joon Sung, Dae-Hwan Kim and Yun Seon Do. 2021. Design of Grating $\mathrm{Al}_{2} \mathrm{O}_{3}$ Passivation Structure Optimized for High-Efficiency $\mathrm{Cu}(\mathrm{In}, \mathrm{Ga}) \mathrm{Se}_{2}$ Solar Cells, Sensors 2021, 21, 4849.

[26] Shi Luo, Carissa Eisler, Tsun-Hsin Wong, Hai Xiao, Chuan-En Lin, Tsung-Ta Wu, Chang-Hong Shen, Jia-Min Shieh, ChuangChuang Tsai, Chee-Wee Liu, Harry A. Atwater, William A. Goddard III, Jiun-Haw Lee, Julia R. Greer.2016. Suppression of surface recombination in $\mathrm{CuInSe}_{2}$ (CIS) thin films via Trioctylphosphine Sulfide (TOP:S) surface passivation, ActaMaterialia 106,171-181

[27] MohitSood, Alberto Lomuscio, Florian Werner, Aleksandra Nikolaeva, Phillip J. Dale, Michele Melchiorre, JérômeGuillot, Daniel Abou-Ras, and Susanne Siebentritt.2021. Passivating Surface Defects and Reducing Interface Recombination in CuInS2 Solar Cells by a Facile Solution Treatment Sol. RRL 5, 2100078

[28] Mbow, B., Mezerreg, A., Rezzoug, N. and Llinares, C. 1994.Calculated and Measured Spectral Responses in Near-Infrared of IIIV Photodetectors Based on Ga, In, and Sb, phys. Stat. Sol. (a) 141, 511.

[29] Hovel H. J., Woodall. J. M. 1973. Ga1-x $A_{x} A s$ GaAs P-P-N Heterojunction Solar Cells, J. Electrochem. Soc. 120, 1246.

[30] Keita, E.M., Mbow, B., Sow., M.L., Thiam., M., Sene. C. 2016. Theoretical Comparative Study of Internal Quantum Efficiency of Thin Films Solar Cells Based on CuInSe 2 : $\mathrm{p}+/ \mathrm{p} / \mathrm{n} / \mathrm{n}+, \mathrm{p} / \mathrm{n} / \mathrm{n}+, \mathrm{p}+/ \mathrm{p} / \mathrm{n}$ and $\mathrm{p} / \mathrm{n}$ Models. International Journal of Engineering Sciences \& Research Technology, 5(9): September, 344-359.

[31] El Hadji Mamadou KEITA, 2017. Doctoral Thesis, Etude théorique de réponses spectrales de cellules solaires à base de $\mathrm{CuInSe}_{2}$ : Modèles à 2 couches $(\mathrm{p} / \mathrm{n}$ et $\mathrm{n} / \mathrm{p})$, à 3 couches $(p / n / n+, p+/ p / n, n / p / p+$ et $\mathrm{n}+/ \mathrm{n} / \mathrm{p})$ et à 4 couches $(\mathrm{p}+/ \mathrm{p} / \mathrm{n} / \mathrm{n}+$ et $\mathrm{n}+/ \mathrm{n} / \mathrm{p} / \mathrm{p}+$ ), Université Cheikh Anta DIOP de Dakar, Sénégal P. 24-47.

[32] Keita, E.M., Ndiaye, B., Dia, M., Tabar, Y., Sene, C., Mbow. B. 2020. Theoretical Study of Spectral Responses of Heterojunctions Based on CuInSe 2 and $\mathrm{CuInS}_{2}$. OAJ Materials and Devices, 5(1), 0508

[33] Hovel. H. J. 1975. Semiconductors and Semimetals: Solar Cells', 11, Academic Press. New York, 127.

All (C) 2022 are reserved by International Journal of Advanced Science and Engineering. This Journal is licensed under a Creative Commons Attribution-Non Commercial-ShareAlike 3.0 Unported License. 